Ruminta • A. Wahyudin $\cdot$ M. L. Hanifa

\title{
Pengaruh pupuk N,P,K dan pupuk organik kelinci terhadap hasil sorgum (Sorghum bicolor [Linn.] Moench) di lahan tadah hujan Jatinangor
}

\section{Effects of NPK and rabbit organic fertilizer on yields of sorghum (Sorghum bicolor [Linn.] Moench) in rainfed land Jatinangor}

Diterima : 17 Agustus 2017/Disetujui : 25 Agustus 2017 / Dipublikasikan : 31 Agustus 2017

CDepartment of Crop Science, Padjadjaran University

\begin{abstract}
Nitrogen $(\mathrm{N})$, Phospate $(\mathrm{P})$, and Potassium (K) and rabbit organic fertilizer could effects on growth and yields of crops. The objective of this research was to obtain the optimum dosage of NPK fertilizer and rabbit organic fertilizer on growth and yield of Sorghum (Sorghum bicolor [Linn.] Moench) in rainfed land. The experiment was conducted in rainfed land Jatinangor, Sumedang, West Java with an altitude of $\pm 760 \mathrm{~m}$ up sea level, inceptisols soil and the climate was classified to $\mathrm{C}_{3}$ type according to Oldeman classification. The experiment design used Factorial Randomized Block design. The treatment consisted of two factors, in which each factor was consisted three levels and replicated three times. The dosages of $\mathrm{N}, \mathrm{P}, \mathrm{K}$ fertilizer as the first factor consisted three levels: $75 \%$ of recommendation dosage, $50 \%$ of recommendation dosage, and $25 \%$ of recommendation dosage. The second factor was three levels of the rabbit organic fertilizer, 5 ton/ha compost, 5 ton/ha bokashi, and 5 ton/ha compost $+7,5 \mathrm{ml}$ of rabbit urine. The results showed that the use of fertilizer dosage of N, P, $\mathrm{K} 75 \%$ showed the best independent effect on panicle length, weight of grains per plant and rendement of grain. In the level 5 ton/ha, the compost showed the best effect on spikes length, spikes weight per plant and grain weight per plant. The combination between 5 ton/ha compost and $7,5 \mathrm{ml} /$ plant of rabbit's urine was the highest effect to rendement of grain.
\end{abstract}

Key words : Dosage of N, P, K · Fertilization •

\begin{tabular}{l}
\hline Dikomunikasikan oleh Tati Nurmala \\
\hline Ruminta $^{1} \cdot$ A. Wahyudin \\
1. Mepartemen Budidaya Tanaman Fakultas Pertanian \\
Unpad \\
2. Mahasiswa Fakultas Pertanian Unpad \\
Korespondensi: r_ruminta@yahoo.com
\end{tabular}

Sorghum • Rabbit organic fertilizer

Sari Pupuk NPK dan pupuk organik kelinci mempunyai pengaruh terhadap pertumbuhan dan hasil tanaman, Penelitian ini bertujuan untuk memperoleh dosis pengurangan pupuk NPK dan pemberian pupuk organik kelinci yang terbaik terhadap hasil dan pertumbuhan sorgum (Sorghum bicolor [Linn.] Moench) di lahan tadah hujan. Percobaan yang dilakukan di lahan tadah hujan Jatinangor Sumedang Jawa Barat, dengan ketinggian tempat \pm 760 diatas permukaan laut, jenis tanah inseptisol dan tipe iklim $C_{3}$ menurut Oldeman. Percobaan ini menggunakan metode penelitian eksperimental, berbentuk Rancangan Acak Kelompok dengan pola faktorial. Perlakuan terdiri dari dua faktor, masing-masing faktor terdiri dari tiga taraf dan diulang tiga kali. Faktor pertama adalah dosis pupuk N, P, K terdiri dari tiga taraf, yaitu $75 \%$ dosis rekomendasi, 50\% dosis rekomendasi, 25\% dosis rekomendasi. Faktor kedua adalah jenis pupuk organik yang terdiri dari tiga taraf, yaitu pupuk kandang kelinci 5 ton/ha, bokashi 5 ton/ha, dan pupuk kandang 5 ton/ha + urin kelinci 7,5 $\mathrm{ml} /$ tanaman. Hasil penelitian menunjukkan bahwa penggunaan dosis pupuk N, P, K 75\% memberikan pengaruh mandiri yang terbaik terhadap panjang malai, bobot biji per tanaman dan rendemen perontokan biji. Perlakuan pupuk kandang 5/ha memberikan pengaruh mandiri yang terbaik terhadap panjang malai, bobot malai per rumpun dan bobot biji per tanaman. Perakuan pupuk kandang 5 ton/ha + urin kelinci $7,5 \mathrm{ml} /$ tanaman memberikan pengaruh mandiri yang terbaik terhadap rendemen kerontokan.

Key words : Dosis N, P, K • Pemupukan • Sorgum $\cdot$ Pupuk organik kelinci 


\section{Pendahuluan}

Sorgum (Sorghum bicolor [Linn.] Moench) merupakan salah satu jenis tanaman serealia yang mempunyai potensi besar untuk dikembangkan di Indonesia karena mempunyai sifat adaptasi yang baik. Tanaman sorgum toleran terhadap kekeringan, dapat berproduki pada lahan marginal, serta relatif tahan terhadap gangguan hama/ penyakit. Sorgum merupakan komoditas alternatif untuk pangan, pakan, dan industri. Biji sorgum mempunyai nilai gizi yang tinggi seperti tanaman serelia lainnya, namun kandungan tanin yang tinggi menyebabkan pemanfaatannya masih terbatas (Sirappa, 2003). Tanaman sorgum termasuk tanaman pangan (biji-bijian) yang banyak dimanfaatkan sebagai pakan ternak (livestock fodder). Tanaman sorgum sering disebut sebagai bahan baku industri bersih (clean industry) karena hampir semua komponen biomassa dapat dimanfaatkan untuk berbagai keperluan industri. Pemanfaatan sorgum secara umum diperoleh dari hasil-hasil utama (batang dan biji) serta limbah (daun) dan hasil ikutannya (ampas/bagasse) (Sumantri dkk., 1996).

Tanaman sorgum di Indonesia sebenarnya sudah sejak lama dikenal tetapi pengembangannya tidak sebaik padi dan jagung, hal ini masih disebabkan masih sedikitnya derah yang memanfaatkan tanaman sorgum sebagai bahan pangan dan masih terbatasnya informasi budidaya yang baik untuk tanaman tersebut. Tanaman ini mempunyai prospek yang sangat baik untuk dikembangkan secara komersial sebagai pangan alternatif untuk memenuhi kebutuhan akan pangan non beras di Indonesia, karena didukung oleh kondisi agroekologis dan ketersediaan lahan yang cukup luas. Sorgum juga sangat potensial unuk diangkat menjadi komoditas agroindustri karena mempunyai beberapa keunggulan seperti dapat tumbuh dilahan kering dan sawah pada musim kering atau kemarau, resiko kegagalan kecil dan pembiayaan (input) usaha taninya relatif rendah. Selain budidaya yang mudah, sorgum juga mempunyai manfaat yang sangat luas antara lain untuk pakan ternak, bahan baku industri makanan dan minuman, bahan baku untuk media jamur merang (mushroom), industri alkohol, bahan baku ethanol dan sebagainya (Mudjisihono dan Damarjati, 1987).

Kendala utama jenis tanah ini untuk dikembangkan sebagai lahan pertanian adalah $\mathrm{pH}$ tanahnya masam, ketersediaan unsur hara
N, P, K, serta kandungan bahan organik yang rendah. Oleh karena itu penambahan unsur hara sangat mutlak diperlukan dalam proses budidaya tanaman pada tanah-tanah ini. Penambahan unsur hara ini dapat dimulai dengan penambahan bahan organik sebagai bio fertilizer yang mempunyai efek simultan terhadap perbaikan sifat-sifat tanah (Subagyo dkk., 2000). Pupuk kandang yang sering digunakan dalam usaha tani biasanya berasal dari kotoran sapi dan domba. Dalam percobaan ini digunakan kotoran dari hewan ternak kelinci yang sudah banyak dibudidayakan sebagai hewan peliharaan maupun konsumsi, namun penggunaan kotorannya belum banyak digunakan oleh petani.

Keergantungan yang besar terhadap pupuk NPK sebagai sumber hara berpotensi menurunkan produktivitas lahan, sehingga penggunaannya perlu dikurangi dengan memanfaatkan pupuk organik yang tersedia dimanamana dan belum dimanfaatkan secara optimal. Pupuk organik digunakan untuk meningkatkan kesuburan tanah, meningkatkan kadar bahan organik tanah, menyediakan unsur hara makro walaupun dalam jumlah yang sedikit dan unsur hara mikro, serta memperbaiki struktur tanah. Pupuk kandang merupakan salah satu pupuk organik hasil yang cukup penting, terdiri dari kotoran padat dan cair dari hewan ternak yang bercampur sisa makanan, dapat menambah unsur hara dalam tanah (Sarief, 1989). Pemberian pupuk organik ke dalam tanah seperti pupuk kandang, diharapkan mampu memberikan pengaruh terhadap sifat fisika dan kimia tanah. Pengaruh pemberian pupuk organik yang dapat menaikan nilai kandungan C-organik, $\mathrm{pH}$ dan kapasitas tukar kation tanah. Setelah penambahan bahan organik ini tercapai selanjutnya diharapkan dapat berdampak pada makin tersedianya unsur hara bagi tanaman.

Perubahan paradigma konsumen kearah green comodity dan gerakan back to nature yang sangat mempengaruhi perkembangan usaha pertanian mendatang. Meningkatnya kesadaran akan kesehatan telah menyebabkan meningkatnya trend (populer) tanaman organik yang mengakibatkan penggunaan pupuk orgnik dari unggas dan ruminansia meningkat. Permintaan pupuk organik yang semakin tinggi dari unggas maupun ruminasia sehingga semakin sulit diperoleh karena harganya semakin mahal. Upaya untuk mengatasi masalah ini penggunaan kotoran kelinci merupakan salah satu 
alternatif sebagai pupuk organik karena peternakan kelinci terus berkembang dengan sistem pemeliharaan ternak tradisional (Sajimin dkk., 2003; Sumarni dkk., 2015). Kelinci dengan berat badan $1 \mathrm{~kg}$ menghasilkan 28,0 g kotoran lunak perhari dan mengandung 3 gram protein serta 0,35 gram nitrogen dari bakteri atau setara 1,3 gram protein (Sumarni dkk., 2015). Riset yang dilakukan Badan Penelitian Ternak (Balitnak) di Ciawi, Kabupaten Bogor, pada 2005 memperlihatkan urine kelinci mengandung unsur $\mathrm{N}, \mathrm{P}$, dan $\mathrm{K}$ masing-masing sebesar lebih tinggi $2,72 \%, 1,1 \%$, dan $0,5 \%$ daripada kotoran dan urine ternak lain seperti sapi, kerbau, domba, kuda, babi, bahkan ayam (Sumarni dkk., 2015).

Hingga saat ini pengaruh pupuk organik kotoran kelenci terhadap pertumbuhan dan hasil tanaman Sorgum belum banyak dipublikasikan. Sementara itu pengaruh pengurangan pupuk NPK dan pupuk organik kandang lainnya terhadap tanaman Sorgum sudah ada beberapa penelitian (Ismaeil et al., 2012; Bahri, 2010; Lithourgidis et al., 2007; Nikus et al., 2004; Ammaji and Suryanarayana, 2003). Hasil penelitian Bahri (2010) menunjukkan bahwa pemberian pupuk $\mathrm{N}, \mathrm{P}, \mathrm{K}$ sesuai dosis anjuran dengan berbagai kombinasi fermentasi cacing tanah pada tanaman sorgum diperoleh hasil tertinggi 3,93 ton/ha. Pengurangan penggunaan dosis pupuk $\mathrm{N}, \mathrm{P}, \mathrm{K}$ mulai dari $75 \%, 50 \%$, dan $25 \%$ secara berurutan diperoleh hasil 3,51 ton/ha, 3, 15 ton/ha dan 3,39 ton/ha dengan menggunakan urin sapi (Kumala, 2011).

\section{Bahan dan Metode}

Percobaan ini dilakukan di lahan tadah hujan dataran medium Jatinangor Sumedang Jawa Barat dengan ketinggian tempat $\pm 760 \mathrm{~m}$ diatas permukaan laut (dpl), tipe curah hujan $C_{3}$ menurut klasifikasi Oldeman (Oldeman, 1975), dan jenis tanah ordo Inceptisol. Metode percobaan yang digunakan adalah percobaan Rancangan Acak Kelompok (RAK) dengan pola faktorial. Perlakuan terdiri dari dua faktor dan masing-masing faktor terdiri dari tiga taraf. Faktor pertama adalah pengurangan dosis pupuk N, $\mathrm{P}, \mathrm{K}$ (I) dengan 3 taraf yaitu $1_{1}(75 \% \mathrm{~N}$, $\mathrm{P}, \mathrm{K}) ; 1_{2}(50 \% \mathrm{~N}, \mathrm{P}, \mathrm{K})$; dan $1_{3}(25 \% \mathrm{~N}, \mathrm{P}, \mathrm{K})$. Faktor kedua adalah pemberian pupuk padat dan cair kelinci $(\mathrm{k})$, dengan 3 taraf yaitu $\mathrm{K}_{1}$ Pupuk kandang 5 ton/ha (kandungan C-organik
11,58); K 2 Pupuk bokashi 5 ton/ha (kandungan C-organik 10,57); dan $\mathrm{K}_{3}$ Pupuk kandang 5 ton/ha + urin 500L/ha (kandungan C-organik 13,28). Adapun dosis anjuran adalah Urea $(\mathrm{N})$ adalah $200 \mathrm{~kg} / \mathrm{ha}, \mathrm{SP}-36$ (P) adalah $125 \mathrm{~kg} / \mathrm{ha}$, KCL (K) adalah $50 \mathrm{~kg} / \mathrm{ha}$. Pengaruh perlakuan diuji statistik dengan Uji $\mathrm{F}$ pada taraf $5 \%$ dan perbedaan nilai rata-rata perlakuan diuji dengan menggunakan Uji Duncan Multiple Range test pada taraf nyata $5 \%$

Pengolahan lahan, penanaman, pemeliharaan, dan pengairan tanaman sorgum untuk semua perlakuan dibuat seragam sedangkan pemupukan tanaman Sorgum disesuaikan dengan perlakuan. Tanaman Sorgum menggunakan jarak tanam $75 \times 20 \mathrm{~cm}$. Pada percobaan ini dosis pupuk anorganik (N, P, K) dikurangi menjadi $75 \%, 50 \%, 25 \%$ dari dosis rekomendasi urea $200 \mathrm{Kg} / \mathrm{ha}$, SP-36 sebanyak $125 \mathrm{~kg} / \mathrm{ha}$, dan KCL sebanyak $50 \mathrm{~kg} / \mathrm{ha}$ (Nurmala dan Irawan, 2007). Penggunaan kotoran kelinci yaitu pupuk kandang dan bokashi satu minggu sebelum tanam. Pengamatan terdiri dari komponen hasil dan hasil tanaman Sorgum yaitu panjang malai, bobot malai per rumpun, bobot 1000 biji, bobot biji per tanaman, bobot biji per petak, bobot biji per hektar, rendemen perontokan biji, dan indeks panen.

\section{Hasil dan Pembahasan}

Hasil analisis ragam terlihat tidak terjadi pengaruh interaksi antara perlakuan pengurangan pemupukan $\mathrm{N}, \mathrm{P}, \mathrm{K}$ dan pupuk organik kelinci terhadap panjang malai, bobot malai, dan bobot 1000 biji. Hasil uji lanjut pengaruh pengurangan pupuk $\mathrm{N}, \mathrm{P}, \mathrm{K}$ dengan penggunaan berbagai macam pupuk organik terhadap panjang malai, bobot malai, dan bobot 1000 biji secara mandiri dapat dilihat pada Tabel 1.

Tabel 1 menunjukan bahwa pengurangan pupuk NPK dan penggunaan pupuk kelinci menunjukan hasil yang tidak berbeda nyata pada komponen hasl panjang malai. Hal ini disebabkan dalam memasuki fase generatif unsur hara makro seperti fosfor dan kalium berpengaruh terhadap pembentukan karbohidrat, efisiensi mekanisme aktivitas serta membantu pembentukan protein dalam tanaman (Nurmala dkk., 2004). Penggunaan pupuk kandang dalam percobaan ini memberikan hasil yang terbaik terhadap bobot malai karena di 
dalam pupuk organik ini terdapat unsur hara makro meskipun dalam jumlah yang relatif sedikit. Besarnya bobot malai per rumpun sangat ditentukan oleh bulir-bulir biji yang tumbuh pada malai tersebut. Malai juga melakukan proses fotosintesis meski tidak sebesar daun. Pengisian biji merupakan penyimpanan fotosintat yang berlangsung dalam malai, bersama dengan bahan yang dimobilisasi kembali dari penimpanan sementara dalam bagian-bagian tanaman lain terutama bagian daun-daun atas dan ruas-ruas batang (Goldsworthy dan Fischer, 1996). Bobot 1000 biji terkait dengan ukuran biji yang merupakan petunjuk seberapa besar endosperm pada biji tersebut. Pada percobaan ini bobot 1000 biji menunjukkan hasil yang tidak berbeda nyata dan pengaruh mandiri menunjukkan perlakuan dengan penggunaan pupuk N, P, K sebesar $75 \%$ memberikan hasil yang terbaik hal ini dikarenakan unsur jara makro berperan penting terhadap pertumbuhan baik vegetatif maupun generatif (Afzal et al., 2012; Abuswar and Mohammed, 1997). Besarnya endosperm biji terutama karbohidrat yang terbentuk dalam biji merupakan hasil penumpukan asimilat selama fotosintesis. Karbohidrat utama pada biji sorgum terdapat dalam bentuk pati (Lal et al., 2000; Mudjisihono dan Damarjati, 1987).

Tabel 1. Pengaruh Pengurangan Pupuk N, P, K dan Pemberian Pupuk Kelinci terhadap Panjang Malai, Bobot Malai, dan Bobot 1000 Biji.

\begin{tabular}{|c|c|c|c|}
\hline \multirow[b]{2}{*}{ Perlakuan } & \multicolumn{2}{|c|}{ Komponen Hasil } & \multirow{2}{*}{$\begin{array}{c}\text { Hasil } \\
\text { Bobot } \\
1000 \text { Bij } \\
(\mathrm{g})\end{array}$} \\
\hline & $\begin{array}{c}\text { Panjang } \\
\text { Malai } \\
\text { (cm) }\end{array}$ & $\begin{array}{l}\text { Bobot Malai } \\
\text { per Rumpun } \\
\text { (g) }\end{array}$ & \\
\hline \multicolumn{4}{|c|}{ Pengurangan NPK } \\
\hline $\mathrm{I}_{1}$ & $27,028 \mathrm{~b}$ & $56,472 \mathrm{a}$ & $29,650 \mathrm{~b}$ \\
\hline $\mathrm{I}_{2}$ & $25,347 \mathrm{a}$ & $58,083 \mathrm{a}$ & $26,885 \mathrm{a}$ \\
\hline $\mathrm{I}_{3}$ & $26,389 \mathrm{ab}$ & $56,972 \mathrm{a}$ & $25,845 \mathrm{a}$ \\
\hline \multicolumn{4}{|c|}{ Pupuk Kelinci } \\
\hline $\mathrm{K}_{1}$ & $27,069 \mathrm{~b}$ & $65,833 \mathrm{~b}$ & $26,979 \mathrm{a}$ \\
\hline $\mathrm{K}_{2}$ & 25,361 a & 51,944 a & $27,868 \mathrm{a}$ \\
\hline $\mathrm{K}_{3}$ & $26,333 \mathrm{ab}$ & $53,750 \mathrm{a}$ & $27,534 \mathrm{a}$ \\
\hline
\end{tabular}

Keterangan : Nilai rata-rata perlakuan yang ditandai dengan huruf yang sama tidak berbeda nyata berdasarkan Uji Jarak Ganda Duncan pada taraf nyata $5 \%$

Hasil penelitian menunjukkan bahwa tidak terjadi pengaruh interaksi antara pemupukan $\mathrm{N}$, $\mathrm{P}, \mathrm{K}$ dan pupuk organik kelinci terhadap bobot antara perlakuan biji per tanaman, bobot biji per retak dan bobot biji per hektar. Pengaruh mandiri pengurangan pemupukan $\mathrm{N}, \mathrm{P}, \mathrm{K}$ dan aplikasi pupuk organik kelinci terhadap bobot antara perlakuan biji per tanaman, bobot biji per retak dan bobot biji per hektar ditunjukkan pada Tabel 2.

Tabel 2. Pengaruh Pengurangan Dosis N, P, K dan Pemberian Pupuk Kelinci Terhadap Bobot Antara Perlakuan Biji per Tanaman, Bobot Biji per Petak dan Bobot Biji per Hektar

\begin{tabular}{lccc}
\hline \multirow{4}{*}{ Perlakuan } & \begin{tabular}{c} 
Bobot Biji \\
per \\
\cline { 2 - 4 }
\end{tabular} & $\begin{array}{c}\text { Bobot Biji } \\
\text { per Petak } \\
(\mathrm{Kg})\end{array}$ & $\begin{array}{c}\text { Bobot Biji } \\
\text { per Hektar } \\
\text { (ton/ha) }\end{array}$ \\
\hline \multicolumn{2}{c}{ Pengurangan NPK } \\
$\mathrm{I}_{1}$ & $44,951 \mathrm{c}$ & $1,936 \mathrm{~b}$ & $3,227 \mathrm{~b}$ \\
$\mathrm{I}_{2}$ & $37,457 \mathrm{~b}$ & $1,815 \mathrm{~b}$ & $3,024 \mathrm{~b}$ \\
$\mathrm{I}_{3}$ & $34,442 \mathrm{a}$ & $1,559 \mathrm{a}$ & $2,598 \mathrm{a}$ \\
\hline Pupuk Kelinci & & & \\
$\mathrm{K}_{1}$ & $40,051 \mathrm{~b}$ & $1,815 \mathrm{a}$ & $3,026 \mathrm{a}$ \\
$\mathrm{K}_{2}$ & $36,391 \mathrm{a}$ & $1,722 \mathrm{a}$ & $2,870 \mathrm{~b}$ \\
$\mathrm{~K}_{3}$ & $40,407 \mathrm{~b}$ & $1,722 \mathrm{a}$ & $2,954 \mathrm{~b}$ \\
\hline \hline
\end{tabular}

Keterangan : Nilai rata-rata perlakuan yang ditandai dengan huruf yang sama tidak berbeda nyata berdasarkan Uji Jarak Ganda Duncan pada taraf nyata $5 \%$

Pengaruh mandiri penggunaan pupuk NPK sebesar 75\% lebih tinggi dari perlakuan yang menggunakan pupuk NPK sebesar 25\% pada bobot biji Sorgum baik per tanaman, per petak, maupun per hektarnya. Penggunaan pupuk organik K3 menunjukkan hasil yang terbaik karena penggunaan pupuk organik berfungsi sebagai penyedia unsur hara makro walaupun dalam jumlah yang sedikit dan unsur hara mikro yang dibutuhkan tanaman. Pengaruh mandiri setiap perlakuan memberikan hasil yang berbeda, karena pengurangan dosis pupuk mempengaruhi pertumbuhan tanaman sehingga hasil yang didapat tidak sebaik pada perlakuan dengan dosis paling tinggi yaitu perlakuan L1 dengan dosis $75 \% \mathrm{~N}, \mathrm{P}, \mathrm{K}$ dengan didukung oleh Goldsworthy dan Fischer (1996) yang menyatakan bahwa keberlangsungan pembentukan biji dipengaruhi asimilasi dari fotosintesis dan remobilisasi unsur hara. Peranan hara nitrogen dan fosfor ditranslokasikan dalam fase awal generatif dan didukung oleh hara kalium pada perkembangan biji.

Faktor genetik berpengaruh terhadap karakteristik bobot biji per tanaman. Hal ini disebabkan faktor mobilisasi hara yang cepat dari proses aliran masa dan translokasi dari hara organik cepat mengurai didalam tanaman, dan 
kekurangan dari bahan organik proses penguraian yang lambat sehingga proses tersebut menjadi pembatas bagi pengisian biji sorgum. Faktor lain yang mempengaruhi pengisian biji ini disebabkan oleh daya serap fosfor oleh tanaman karena fosfor memiliki peranan yang penting pada saat fase pematangan dan pengisian biji (Abuswar and Mohammed, 1997). Produktivitas hasil percobaan ini menunjukkan hasil yang tidak berbeda nyata disebabkan karena penggunaan pupuk NPK yang berbedabeda. Konversi bobot biji per retak yang berkisar antara $1,559 \mathrm{~kg} /$ petak sampai $1,936 \mathrm{~kg} /$ petak menjadi 2,598 ton/ha sampai 3,227 ton/ha sehingga hasil tersebut lebih tinggi dari hasil yang ada pada deskripsi tanaman yaitu sebesar 2,67 ton/ha dan 1,5 ton/ha.

Pengaruh pupuk NPK dan pupuk organik kotoran kelinci terhadap rendemen perontokan biji dan indeks panen tidak terjadi pengaruh interaksi. Pengaruh mandiri pengurangan pemupukan $\mathrm{N}, \mathrm{P}, \mathrm{K}$ dan pupuk organik kelinci terhadap rendemen kerontokan dan indeks panen ditunjukkan pada Tabel 3.

Tabel 3. Pengaruh Pengurangan Dosis N, P, K dan Pemberian Pupuk Kelinci Terhadap Rendemen Perontokan Biji dan Indeks Panen

\begin{tabular}{lcc}
\hline \multicolumn{1}{c}{ Perlakuan } & $\begin{array}{c}\text { Rendemen } \\
\text { Perontokan } \\
\text { Biji (\%) }\end{array}$ & $\begin{array}{c}\text { Indeks } \\
\text { Panen }\end{array}$ \\
\hline Pengurangan NPK & & \\
$\mathrm{I}_{1}$ & $86,502 \mathrm{~b}$ & $0,323 \mathrm{a}$ \\
$\mathrm{I}_{2}$ & $69,349 \mathrm{a}$ & $0,289 \mathrm{a}$ \\
$\mathrm{I}_{3}$ & $64,578 \mathrm{a}$ & $0,324 \mathrm{a}$ \\
\hline Pupuk Kelinci & & \\
$\mathrm{K}_{1}$ & $62,954 \mathrm{a}$ & $0,315 \mathrm{a}$ \\
$\mathrm{K}_{2}$ & $78,592 \mathrm{~b}$ & $0,296 \mathrm{a}$ \\
$\mathrm{K}_{3}$ & $78,883 \mathrm{~b}$ & $0,323 \mathrm{a}$ \\
\hline \hline
\end{tabular}

Keterangan : Nilai rata-rata perlakuan yang ditandai dengan huruf yang sama tidak berbeda nyata berdasarkan Uji Jarak Ganda Duncan pada taraf nyata 5\%

Rendemen biji Sorgum berkisar antara $62,95 \%$ sampai $86,50 \%$, dimana perlakuan L1 lebih tinggi dari perlakuan yang lainnya yang disebabkan karena penggunaan pupuk kimia yang tinggi dari perlakuan lainnya. Rendemen biji merupakan perbandingan antara bobot biji dengan bobot malai per tanaman. Rendemen kerontokan dipengaruhi oleh penuh tidaknya malai terisi oleh biji, bila biji yang terbentuk kecil-kecil dan tidak memenuhi malai maka rendemen kerontokan akan lebih kecil dan sebaliknya jika malai terisi penuh oleh biji dan terbentuk besar-besar rendemen kerontokan akan lebih besar.

Indeks panen merupakan perbandinagn antara bobot kering biji terhadap bibit biomassa total. Indeks panen digunakan sebagai suatu ukuran yang mendasari seleksi untuk hasil yang tinggi, tetapi mempunyai batas-batas yang pasti. Nilai indeks panen dapat bervariasi dari 0,289 sampai 0,324 antara kultivar dan nilainya akan bergantung pada lama dan laju pertumbuhan relatif sebelum dan sesudah antesis dan pada pembagian berat kering setelah antesis (Goldsworthy dan Fischer, 1996). Hasil percobaan ini memperlihatkan bahwa indeks panen untuk setiap perlakuan tidak berbeda nyata. Hal ini menunjukkan bahwa tanaman Sorgum mempunyai perbandingan yang relatif sama antara berat bahan kering total dan berat kering biji (Gardner et al., 1991).

\section{Kesimpulan}

Pengaruh dosis pupuk N, P, K 75\% memberikan hasil yang terbaik terhadap bobot biji per tanaman dan penggunaan pupuk kandang 5 ton/ha dengan kandungan C-organic 10,57 memberikan hasil yang terbaik terhadap bobot biji per tanaman dan rendemen biji. Penggunaan pupuk kandang 5 ton/ha memberikan pengaruh mandiri yang terbaik terhadap panjang malai, bobot malai per rumpun dan bobot biji per tanaman. Pupuk Kandang 5 ton/ha + urin kelinci 7,5 ml/ha dengan kandungan C-organik 13,28 memberikan pengaruh mandiri yang terbaik terhadap rendemen biji. Penggunaan pupuk NPK untuk tanaman sorgum yang ditanam di lahan tadah hujan Jatinangor direkomendasikan sebesar $75 \%$ dari dosis anjuran yaitu $150 \mathrm{~kg} /$ ha Nitrogen, 93,75 kg/ha Phosfat, dan 37,5 kg/ha Kalium.

\section{Daftar Pustaka}

Abuswar, A.O. and G.G. Mohammed, 1997. Effect of nitrogen and phosphorus fertilization on growth and yield of some graminacea forage. Journal of Agric. Sci., $5(2): 25-33$.

Afzal, M., A. Ahmad, and A. H. Ahmad. 2012. Effect of Nitrogen on Growth and Yield of Sorghum Forage (Sorghum Bicolor (L.) 
Moench Cv.) under Three Cuttings System. Cercetări Agronomice în Moldova, 45(4).

Ammaji, P. and K. Suryanarayana, 2003. Response of fodder sorghum varieties to different levels of nitrogen. J. Res. Angrau., 31(2): 109-112

Bahri, S. 2010. Pengaruh Pemupukan Nitrogen dan Fermentasi Cacing tanah (Lumbricus rubellus) Terhadap Pertumbuhan dan Hasil Sorgum (Sirghum bicolor (Linn) Moench) Genotip 4.1 pada Tanah Inseptisol. Skripsi Universitas Padjadjaran.

Gardner, F.P., R.B. Pearce, dan R.L. Mitchell. 1991. Fisiologi Tanaman Budidaya. Indonesia University Press, Jakarta.

Goldsworthy, P.R. dan N.M. Fischer. 1996. Fisiologi Tanaman Budidaya Tropika. GMU Press, Yogyakarta.

Ismaeil, F.M., A.O. Abusuwar, and A.M. El Naim. 2012. Influence of Chicken Manure on Growth and Yield of Forage Sorghum (Sorghum Bicolor L.Moench), Int'1 Journal of Agriculture and Forestry, 2(2): 56-60.

Kumala, R.G. 2011. Pengaruh Pemupukan N, P, K dan Urine Sapi Terhadap Pertumbuhan dan Hasil Tanaman Sorgum (Sorghum bicolar [Linn.] Moench) Pada Tanah Inceptisol. Skripsi Universitas padjadjaran .

Lal, B.S. and S. Mohammad, 2000. Nutrient enrichment effect of parental lines on crop growth, yield components and yield of seed parent AKMS-14A for CHS-14 sorghum hybrid seed production. Crop Res., 20: 25-8.

Lithourgidis, A.S., T. Matsi, N. Barbayiannis, and C.A. Dordas. 2007. Effect of liquid cattle manure on corn yield, composition and soil properties. Agron. J., 99:1041-1047.

Oldeman, J. 1975. Agroclimatic Map of Java. Central Crop Research Institution. Bogor. Indonesia.

Mudjisihono, R., dan D.S. Damarjati. 1987. Prospek kegunaan Sorghum sebagai sumber pangan dan pakan ternak. J. Litbang Pertanian 6(1): 1-4.

Nikus, O., M.A.Turk, and A.R.M. Al-Tawaha. 2004. Yield Response of Sorghum (Sorghum bicolor L.) to Manure Supplemented with Phosphate Fertilizer Under Semi-arid Mediterranean Conditions. Int. J. Agri. Biol., 6(5).

Nurmala, T., A.W. Irwan, dan A. Wahyudin. 2004. Tekonologi Peningkatan Produksi Tanaman. Giratuna. Bandung.

Nurmala, T. dan A.W. Irwan. 2007. Pangan Alternatif Berbasis Serealia Minor. Giratuna. Bandung.

Sajimin, C, Yono. Rahardjo, D. Nurhayati dan Purwantari. 2003. Potensi kotoran kelinci sebagai pupuk organik dan pemanfaatannya pada tanaman pakan dan sayuran. Lokakarya Nasional Potensi dan Peluang Pengembangan Usaha Agribisnis Kelinci. Tahun 2003.

Sirappa, M.P. 2003. Prospek Pengembangan Sorgum di Indonesia Sebagai Komoditas Alternatif untuk Pangan, Pakan, dan Industri. Jurnal Litbang Pertanian, 22(4).

Subagyo, H., Suharta, dan B. Siswanto. Tanah Tanah Pertanian di Indonesia. Pusat Penelitian Tanaman Pangan Bogor.

Sumarni, S., Sukatiman, E. Sri, dan A.Adenata. 2015, Usaha Budidaya Kelinci Terpadu. Prosiding Seminar Nasional 4th UNS SME's Summit \& Awards Tahun 2015.

Sumantri, A., Hanyokrowati, dan B. Guritno. 1996. Prospek Pengembangan Sorgum Manis untuk Menunjang Pembangunan Agroindustri di Lahan Kering. Prosiding Seminar dan Lokakarya Nasional Pertanian Lahan Kering Beberapa Kawasan Pembangunan Ekonomi Terpadi di Kawasan Timur Indonesia. Malang, 10-12 Oktober 1996.

Syarif, S. 1989. Kesuburan dan Pemupukan Tanah Pertanian. Pustaka Buana. Bandung. 